Originalveröffentlichung in: W. Briggs - J. Gaisser - C. Martindale (Hg.) A companion to the classcal tradition,

Malden 2007, S. 169-191

\title{
CHAPTER TWELVE
}

\section{Germany and German-Speaking Europe}

\author{
Volker Riedel
}

\section{The Middle Ages}

Classical, predominantly Roman, culture had continued to influence most Germanic tribes, especially the Ostrogoths but also the Franks under Merovingian rule, following the late classical and early medieval Christianization of Europe. However the first major reorientation of the Roman Catholic Middle Ages to its classical inheritance took place later, from the second half of the eighth to the beginning of the tenth century, under the Carolingians. Charlemagne (768-814, crowned emperor 800) initiated this cultural renewal, the so-called "Carolingian Renaissance." Reaching back to late antiquity in particular, it led to a synthesis of Germanic traditions, classical culture, and Christianity. Charlemagne undertook a far-reaching reform of the educational system, as part of his attempt to emulate the former Roman emperors and to gain preeminence for the Frankish state in western Europe, as a counterweight to the Byzantine empire in the east. He attracted scholars from across Europe to his court, including the Anglo-Saxon Alcuin (ca. 730-804), the Lombard Paul the Deacon (ca. 720 - ca. 799), and the Visigoth Theodulf (ca. 760-821). Alcuin, the most significant scholar of his age, wrote theological treatises and textbooks on grammar, rhetoric, and dialectic as well as on lyric verse and fables. Yet his main legacy lies in advancing education by rediscovering classical achievements (especially the concept of the septem artes liberales [seven liberal arts] as constituting the basic curriculum), which exerted a lasting influence throughout the Middle Ages. Monasteries and cathedral schools played an important role, in particular the Benedictine abbey of Fulda and its abbot, the first Germanic theologian and polyhistorian Hrabanus Maurus (ca. 776/ 84-856, abbot 822-42), the most influential scholar of the late Carolingian era.

Collections of glosses and interlinear versions had already been created around 760 , but under Charlemagne and his successors numerous works of Roman literature were 
copied. A new script that followed Roman models - the Caroline minuscule - was invented, and Vergil and the Roman historians served as models for poetic and historical writings. Einhard (ca. 770-840), a Frankish scholar, followed Vitruvius in his concern for architectural construction and Suetonius in his Vita Caroli Magni (Life of Charlemagne). Biblical poetry such as the Old Saxon Heliand (ca. 830) and the Old High German Book of the Gospels, which Otfrid von Weißenburg completed around 865 , was influenced by Fulda, and thus by late classical traditions. Notker I of St. Gall (Notker Balbulus, ca. 840-912), who composed the Gesta Karoli (Deeds of Charles [III]) and the Vita Sancti Galli (Life of St. Gall), was the major lyric poet of the early Middle Ages who invented the genre of Latin sequences. Early Romanesque architecture, such as the palace chapel in Aachen and the monastery of Lorsch, followed late classical and early Christian models, as did the visual arts of illuminations, frescoes, small-scale sculpture, jewelry-making, coins, and gems.

Subsequently the Frankish lands were divided, the German empire was established, and the Saxon house of the Ottonians came to power (first quarter of the tenth to the first quarter of the eleventh century). A renewed, more pronounced orientation toward classical antiquity began under Otto I (936-73, crowned emperor 962) and his successors, which extended into the first years of the reign of the Salian Henry II (1039-56, crowned emperor 1046). The expression renovatio imperii Romanorum (renewal of the Roman empire) was used, but Greco-Byzantine influences were also acknowledged. This so-called "Ottonian Renaissance" did, however, retain a greater independence from antiquity than that of the Carolingians. In northern Germany, the chapterhouse of Magdeburg and the monastery at Corvey on the Weser River were centers of spirituality, as were the monasteries of St. Gall and Reichenau on Lake Constance in the South. Literature was composed mostly in Latin. In Saxony, Hrotsvitha von Gandersheim (ca. 935 - ca. 975) modeled her six plays in rhythmic prose on Terence, although she approached his work from a Christian perspective. Widukind von Corvey (died 1004), who wrote the chronicle Res gestae Saxonicae (Saxon deeds), was another important Saxon author. Key figures in St. Gall were Ekkehard I (after 900-73), Notker III (Notker Labeo or Notker Teutonicus, ca. 950-1022), and Ekkehard IV (ca. 980-1060). The Waltharius, written or transmitted by Ekkehard I, renders the lost Old High German Waltharilied (Song of Waltharius) in Latin hexameters and often echoes Vergil. The polyhistorian Notker III was the only poet of his generation to translate into German, composing, for instance, a treatise on music in the tradition of Boethius, as well as writing in Latin. Ekkehard IV distinguished himself as a linguist, lyric poet, and chronicler of the monastery of St. Gall. On the island of Reichenau, Hermann von Reichenau (1007-54) wrote among other works a history of the world (Chronica) from the birth of Christ up to his own time. The Ecbasis cuiusdam captivi (The escape of a certain prisoner) (ca. 936), the oldest animal epic in German literature, uses motifs from Aesop's fables and the Physiologus and regularly quotes Vergil, Horace, Ovid, and other Roman writers. In all likelihood it was the work of a monk from Toul in Lothringia. Traditions stemming from late antiquity were continued in architecture in, for example, the cathedral and imperial palace of Magdeburg and in Bamberg Cathedral, but also in illumination (which was now flourishing on the Reichenau) and in jewelry-making. 
Under the Frankish dynasty of the Salians from the second quarter of the eleventh to the first quarter of the twelfth century, the power of the monarchy was strengthened. Subsequently, the emperor, the German nobles, and the papacy started to vie for supremacy in the empire during the investiture struggle. These disputes between church and state were conducted in part utilizing Roman rhetoric and dialectic. Most literary production was of a spiritual nature, as part of the movement toward religious renewal and monastic reform. Echoes of classical poetry can be found in the Latin verse epic Ruodlieb (mid-eleventh century), composed in leonine (rhyming) hexameters, and in the Latin-German Hohelied (High song) poetry and exegesis of Williram von Ebersberg (1048-85). The Romanesque architecture and plastic arts of the eleventh and twelfth centuries employed Roman models and techniques: the cathedrals of Speyer, Worms, and Mainz are based on the Roman basilica and use round arches, columns, pillars, barrel vaults, cupolas, and portals. In sculpture, simple imitation, such as crafting reliefs, was widespread, while metalwork most closely followed antique models.

Medieval culture reached its zenith between the mid-twelfth and the mid-thirteenth centuries during a period of change and innovation in Europe, the "twelfth century (or Hohenstaufen, after the ruling family) renaissance." This Swabian dynasty saw the empire as extending across Germany, Italy, and Burgundy, and as independent of the papacy, in accordance with a theory developed since the late tenth century and systematized from the end of the eleventh century. Partly based on Jerome and Orosius, four empires were seen to follow one after the other: the Babylonian, that of the Medes and Persians, the Greek, and the Roman. The theory then states that the rule of the Roman Empire - the final one before the world comes to an end - had been passed on by the Romans to the Franks and then on to the Germans, through the translatio imperii (passing on of the empire). Roman law was researched extensively, increasingly so in the late medieval and early modern period, and its influence is still palpable today. In 1157 during the reign of Frederick I (Barbarossa, 1152-90, crowned emperor 1155), the empire was first called Sacrum imperium, as well as simply imperium or imperium Romanum; later Sacrum imperium Romanum (Holy Roman empire) was commonly used. Frederick II (1212-50, crowned emperor 1220) even replicated elements of the emperor cults of late antiquity and introduced religious overtones to his rule.

As a consequence of the Crusades, medieval culture at its high point became better acquainted with Byzantine and Arabic, and through them Greek, culture. Following Augustine and Boethius, the theology and philosophy of the early Middle Ages had been characterized more by Neoplatonic, and less by Aristotelian, influences. But Aristotle's works, which had been translated from Greek into Arabic, were now again made more widely accessible by translating the Arabic itself into Latin. Albertus Magnus (ca. 1193-1280), the most significant German scholar of this period, wrote theological and scientific treatises. Through them and his pupil Thomas Aquinas, he ensured that a Christianized Aristotelian approach provided the foundation for the flourishing of Scholasticism. Supported by the knights, the literature of the Hohenstaufen period turned to worldly, and in particular courtly, concerns, with its most important works composed in German. Epic verse was the dominant genre, 
beginning with the Alexanderlied (Song of Alexander), written around 1130/50 by Lamprecht, a priest from Trier, after a French model. The Eneit of Heinrich von Veldeke (between 1140 and 1150 - before 1210) followed the French Roman d'Énéas as well as using Vergil's own Aeneid, showing the way for the courtly and artful epic of the high Middle Ages. The poem presents exemplary knightly behavior, fulfilling the requirements of courtly ceremony, itself founded on the bohe Minne (courtly love): in a departure from Vergil, increased attention is paid to Aeneas' love for Lavinia, which is juxtaposed to the hero's passionate relationship with Dido. This epic was completed around 1200 at the court of the Count of Thuringia, a center for the reception of classical literature. From Thuringia, we also have the Trojaroman (Story of Troy) of Herbort von Fritzlar (after 1190) after Benoit de Sainte-Maures' Roman de Troie, and the rendition of Ovid's Metamorphoses in German rhyming couplets by Albrecht von Halberstadt (ca. 1210/17). Ovidian influences are also at work in goliardic verse (Archipoeta [born ca. 1130/40]), in the Carmina Burana (mid-thirteenth century), in the works of Minnesänger (minnesingers), and in the

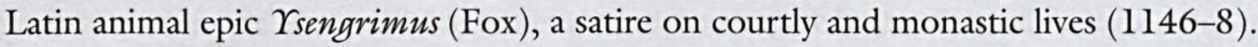
Otto von Freising's (ca. 1114-58) universal history Chronica sive Historia de duabus civitatibus (Chronicle or history of two states), modeled on Augustine, marks the high point of medieval historiography. Classical influences were less visible in architecture and sculpture, although stones from antique buildings were increasingly reused. However, a bronze head of Frederick I, the Head of Cappenberg, cast soon after 1155, portrays him wearing the fillet and laurel crown of a Roman emperor, and under Frederick II larger-scale sculpture developed at a greater pace.

The Gothic style, which was predominant in Europe from the thirteenth to the fifteenth century, was less closely connected to antiquity. Although architects retained the basic shape of the basilica of the early Christian Roman church, classical decorative architectural elements and imagery were only employed in a limited way. A clear indication is the shift from the round to the pointed arch. Sculpture, drawing, and painting only occasionally looked back to antiquity, and even then in only rudimentary fashion. There were, however, many illustrations to classical texts, as demanded by their subject matter, and antique models for sepulchral sculpture and epitaphs gained in importance. Latin itself continued to play a crucial role during the late Middle Ages. With the rise of the urban centers and their citizens, it now came to be taught more in the Latin schools of the towns than in the monastic and cathedral schools.

\section{The Renaissance}

The court of Charles IV (1346-78, crowned emperor 1355) of the house of Luxembourg in Prague was the first to show signs of the Renaissance, even if only briefly and limited to this area of the empire. The Italian humanists Francesco Petrarca and Cola di Rienzo both resided there temporarily. The humanism of the Renaissance actually began to take hold in Germany from the middle of the fifteenth century. The invention of letterpress printing contributed to this, as did the humanists' 
dominance in Italy and their contacts with German scholars, and the passing of the title of emperor from the Luxembourg to the Habsburg dynasty (1438). The fall of Constantinople to the Turks (1453) and the subsequent expulsion of Greek scholars brought a deeper understanding of Greek to western Europe, which up to then had been influenced mostly by Latin. The Renaissance was marked by a number of important changes: from a culture of courts and knights to that of an urban citizenry, from the emperor's and pope's claims to universal rule to the emergence of the nation state, of geographically based rule, and of different confessions. During the Middle Ages the classical inheritance provided the basis for culture, insofar as it could be reconciled with Christianity. The "rebirth" of antiquity, however, brought a very different, new approach, as illustrated by the increasingly secular nature of people's lives, the exploration of the globe and of humanity, and the regard for the individual, nature, and the nation. A new, historical perspective on antiquity also emerged, as did the emulation of classical Latin, the development of anticlerical tendencies, and the emergence of modern national literatures in their different vernaculars.

Even though the claim to resurrect the Roman Empire had failed with the disintegration of the rule of the Hohenstaufen, it was renewed by the Habsburg emperor Charles V (1519-56, crowned emperor 1530). Only thereafter did the term imperium Romanum lose its claim to universality and come to designate one empire among many, in which sense it continued to be used as a formal title until 1806.

Philosophy and natural sciences, legal and state theory, the arts and especially literature, concomitant with philology and pedagogy, all now reached back to classical thought. Philosophers left behind the now-mechanistic Aristotelian approach of scholasticism and gave increasing importance to Plato and Neoplatonism.

Even before the main period of German humanism, Nikolaus von Kues (Nicolaus Cusanus, 1401-64) spent many years in Italy where he discovered, among other manuscripts, 12 comedies by Plautus. He strove for a synthesis of scholasticism, mysticism, antiquity, and modern natural sciences. The crucial mediator, however, between Italian and German humanism was Enea Silvio Piccolomini (1458-64, Pope Pius II), who lived in Germany for 21 years altogether, including 10 in Vienna, which became a cultural center under Frederick III (1440-93, crowned emperor 1452). These towns and universities in southern and western Germany were also centers of humanism: Basle, Strasbourg, Schlettstadt, Heidelberg, Tübingen, Augsburg, Ingolstadt, and Cologne; in the sixteenth century they were joined by Erfurt, Wittenberg, and Leipzig in central Germany.

While early German humanism (up to around 1485) owed much to Italian influence, it soon developed its own national confidence as well. It focused mostly on absorbing what was already available, through collections of models and translations, but began to innovate in lyric poetry, historiography, and rhetoric. Its most significant literary contributors were Albrecht von Eyb (1420-75), Peter Luder (ca. 1410 - after 1474), Heinrich Steinhöwel (1412-82), and Rudolf Agricola (1444-85). Albrecht von Eyb composed a number of writings about the city of Bamberg, edited the anthology Margarita poetica (a rhetorical textbook and compendium of classical and humanist quotations and maxims), and translated two of Plautus' comedies. Peter Luder, the first representative of German humanism at a university, was famous 
for his 1456 inaugural lecture at Heidelberg and for his Elegia Petri Luderi poetae clarissimi ad Panphilam amicam suam singularem (Elegy of the most famous poet Peter Luder to his most particular [girl-]friend Panphila), which contains many reminiscences of Vergil and other Roman authors. In it Luder shows a considerable poetic self-confidence, introducing the elegiac genre and meter to Germany. The main work of Heinrich Steinhöwel is the Esopus, an edition, translation, and commentary of a range of classical, medieval, and humanist fables and stories, which is marked by a distinctly secular perspective. Rudolf Agricola was the first German humanist to win international acclaim with his voluminous and wide-ranging works. His speech in praise of philosophy and the other sciences given at the inception of the academic year at the University of Ferrara in 1476 stands out, displaying an optimistic view of life.

The time between 1485 and 1520 can be described as the high point of humanism in Germany. In addition to the editing and translating of texts, new works were increasingly being created, from plays, a number of lyrical genres, letters, and treatises to a range of satirical and humorous writings. The first significant German poet composing in Latin and the greatest lyrical talent of German humanism was Conrad Celtis (1459-1508). From 1497 he was active in Vienna, which continued to be a cultural center under Maximilian I (1493-1519, crowned emperor 1508). His programmatic ode Ad Apollinem (To Apollo) proclaims the Muses to be at home in Germany forthwith, while his inaugural lecture of 1492 at Ingolstadt asks his audience to strive for fame, virtue, and true immortality following the examples of classical philosophers, poets, and orators. Celtis wrote plays (such as Ludus Dianae [Play of Diana]), elegies (the Quattuor libri amorum secundum quattuor latera Germaniae [Four books of loves according to the four sides of Germany], his greatest work), odes, and epigrams. Sebastian Brant (1457-1521) employed in his Narrenschiff (Ship of fools) countless classical examples; particularly impressive are Odysseus and Heracles. Jacob Locher (1471-1528) translated this work into Latin and wrote poems, speeches, and plays (such as the Iudicium Paridis de pomo aureo, or Paris awarding the golden apple). The motif of a contest (judgment of Paris and Heracles at the crossroads) was one of the most popular in the literature and paintings of the sixteenth and seventeenth centuries. The first German rendition of Vergil's Aeneid by Thomas Murner (1475-1537) was a significant achievement. Desiderius Erasmus of Rotterdam (1466-1536) received recognition as the undisputed leader of German humanism; the most important among his many and varied writings are the Adagia (a collection of Latin sayings, maxims, parables, examples, and metaphors with a commentary and index), the witty Morias encomion seu laus stultitiae (Praise of folly), and his critical edition of the New Testament.

During the height of humanism, German sculpture, design, and painting developed with particular confidence, taking classical subjects and forms as their guideline and focusing on the secular world. The newly discovered physical nature and beauty of the human form stood at the center of German Renaissance art. Albrecht Dürer (1471-1528) was the artist whose theory and practice were most strongly influenced by antiquity. The Isenheimer Altar by Mathis Gothart-Nithart (Grünewald, ca. 1460-1528) also deserves to be mentioned. 
The polemical and anticlerical phase of German humanism began around 1510. It culminated in the Hebrew controversy between Johannes Reuchlin (1455-1522) and the converted Jew Johannes Pfefferkorn of Cologne (1469-1521), who called for all Jewish writings to be burned. All major German humanists supported Reuchlin. The satire Epistolae obscurorum virorum (Letters of obscure men), published in 1515 and 1517, attacked scholasticism and its nonclassical Latin as well as the feigned spirituality of the clergy. The main author of the second part of the "Dark Men's Letters" was Ulrich von Hutten (1488-1523), who shortly afterwards started to write in German instead of Latin. His letter of October 25, 1518, to the Nuremberg patrician Willibald Pirckheimer (1470-1530), one of the most brilliant figures of the humanism of the Renaissance in Germany, includes these words: $O$ saeculum! O litterae! Invat vivere (O times! O literature! It is pleasant to be alive). The circle of humanists in Erfurt around Konrad Mutianus Rufus (1471-1526) also gained recognition; it included Crotus Rubeanus (1480-1539), another author of the "Dark Men's Letters," Helius Eobanus Hessus (1488-1540), who was noted for his eclogues, heroides, and elegies, and the epigrammatist Euricius Cordus (1486-1535).

From about 1520 German humanism was more or less marked by the Reformation and mirrored the changes and differentiated developments that accompanied it. Even though the Reformation had been prepared for, to an extent, by humanism, and even though Martin Luther (1483-1546) as well as Huldrych Zwingli (1484-1531) and Johann Calvin (1509-64) had been influenced by it, the studia humanitatis (liberal arts) became the medium and foundation that led to the studia sacrarum litterarum (religious studies). Luther showed concern for ensuring that the Greek and Latin languages, and comedy after the model of Terence, were taught, as well as famously translating the Bible into German. He himself translated 13 of Aesop's fables in such a way as to emphasize their moral, didactic nature, in contrast to Steinhöwel. His friend and fellow reformer Philipp Melanchthon (1497-1560) wrote textbooks on rhetoric, grammar, and dialectics, as well as publishing editions, commentaries, and his own poetry. As praeceptor Germaniae (Germany's teacher), he founded the new, Protestant range of schools and universities. This period saw the creation of a literature of debate and controversy, often satirical, employing classical elements (e.g., from Aristophanes, Lucian, and the rhetorical tradition). Latin, then German, educational drama developed, as did numerous lyrical writings, now taking the form in particular of learned poetry by scholars and priests, which significantly limited the scope of subject matter covered by humanist poetry. Philology continued to flourish, and a number of translations were published, foremost among them being the rendition of the Odyssey by Simon Schaidenreisser (ca. 1500-72). Animal fables and epic were especially valued. Even passion plays and the songs of Meistersänger (master-singers) featured classical motifs (Hans Sachs [1494-1576]).

Biblical, classical, and civic-urban elements combined in the visual arts (Lucas Cranach the Elder [1472-1553], Hans Holbein the Younger [1497/8-1543]). Classical elements were used as features in secular buildings such as town halls (e.g., Görlitz) and palaces (Dresden, Heidelberg), and in Saxony the first Protestant palace chapels were designed (Torgau, Augustusburg). 
The humanism of the post-Reformation in particular witnessed major scientific and technological achievements. Georgius Agricola (1491-1555), a geologist and mineralogist, founded the modern science of coal and iron mining utilizing the works of Hippocrates, Aristotle, Theophrastus, Pliny the Elder, and other classical authors. Influenced by the scientific approach of Hippocrates and Galen, the doctor, chemist, and philosopher Paracelsus (1493-1541) breathed new life into medicine. The mathematician and astronomer Nicolaus Copernicus (1473-1543) took inspiration from the Pythagoreans, Plato, Aristarchus of Samos, and Proclus, and developed his heliocentric view of the universe as a continuation of and improvement on Ptolemy and in critical dialogue with Aristotle's physics. Even the cosmology of Johannes Kepler (1571-1630) was still rooted in Renaissance Platonism and in its classical sources, which influenced both the mathematical understanding of the universe and the concept of a universal harmony.

\section{The Baroque}

Antiquity played a less significant role in Germany during absolutism and the Baroque period (seventeenth and first half of the eighteenth century) than it had done in the Renaissance. Latin gradually gave way in some areas to a modern German literary idiom, and classical authorities were valued less as the natural sciences increasingly relied on experimentation and individual observation. Received paradigms paled in view of the upheavals of that period ("Aber wenn der Tod uns trifft, / Was hilft da Homerus' Schrift?", or "But when Death reaches us, / What use is Homer's verse?" [Paul Gerhardt; cf. Riedel 2000: 83]). However, the engagement with antiquity remained notable in politics, philosophy, literature, music, visual arts, and architecture. This engagement served to develop, and partly already to question, a courtly-aristocratic culture in particular in the decades following the Thirty Years' War (1618-48).

Philosophy and political theory, as well as literary works on historical topics, were dominated by a (neo-)Stoicism influenced heavily by Seneca and first expounded in the treatise De constantia (On constancy) by the Dutch philosopher Justus Lipsius (15471606). This (neo-)Stoicism was closely linked to a Tacitean way of thinking. It had its origins in the crisis of the European monarchies during the religious and civil wars of the sixteenth and seventeenth centuries and consciously borrowed from authors of the Principate.

Martin Opitz (1597-1639) held the greatest significance for Baroque literature. His speech Aristarchus sive de contemptu linguae Teutonicae (Aristarchus or on the neglect of the German language) called for German to be used, and his Buch von der Deutschen Poeterey (Book on German poetry), partly based on Aristotle, Horace, and Quintilian as well as the poetics and poetry of the Renaissance, laid the intellectual foundation for later writers. He led the way for lyric and the novel (including pastoral poetry), and his translations of Seneca's Troades and Sophocles' Antigone became models for later tragedy. Lyric poetry mostly followed Horace (Paul Fleming [1609-40], Jacob Balde [1604-68]). The best-known playwright of the time was Andreas Gryphius (1616-64), who wrote four original tragedies on historical- 
political subject matter, among them Papinian, which was set in the late Principate and reflected the contrast between legal ideals and practice under absolutism and the uneasy situation of a bourgeois hero serving at court.

The history of the early Baroque period was marked by the Thirty Years' War, while its outlook on the world was shaped by the predominance of the vanitas concept, and its aesthetics by a classicism following the influence of the poets of the Renaissance. The high Baroque of the second half of the seventeenth century reflected the postwar period and an increasingly feudal society. The language employed was elegant, sometimes bombastic, and motifs relating to the enjoyment of life and love replaced those of death and the grave, changing from docere (teaching) to delectare (giving pleasure) and from Horace to Ovid. Christian Hofmann von Hofmannswaldau (1617-79) modeled his poetry on Ovid in particular; Daniel Casper von Lohenstein (1635-83) wrote four tragedies on Roman subjects (Cleopatra, Agrippina, Epicharis, and Sophonisbe), which thematized conflicts between reason and passion and exemplified the ambiguity of political action while praising exemplary conduct. His novel Großmütiger Feldherr Arminius (Magnanimous General Arminius), marked by heroism and gallantry, sets Germans against Romans. Other novels (such as the Römische Octavia [Roman Octavia] by Herzog Anton Ulrich von Braunschweig [1633-1714]) and epics likewise bear witness to a courtly approach to Roman history. In contrast, the most important work in prose of this time, Der Abentheurliche Simplicissimus Teutsch (The adventurous greatest German simpleton) by Hans Jacob Christoffel von Grimmelshausen $(1621 / 2-76)$, is rooted in the traditions of popular poetry, although even this novel contains numerous traces of classical writings, especially the Odyssey. The last of the well-known Baroque poets, Johann Christian Günther (1695-1723), preferred those of Ovid's poems that deal with more serious subject matters.

In music and musical theater, opera, which had first been developed around 1600 in Italy, claimed to revive Greek drama. Opitz had already introduced this genre to Germany with his libretto of 1627 for the opera Dafne, composed by Heinrich Schütz (1585-1672). Classical myth and history continued to supply the subject matter for most operas and also influenced oratorios and cantatas: Georg Philipp Telemann (1681-1767) wrote the operas Orpheus und Eurydike, Der geduldige Sokrates (Patient Socrates), and Omphale as well as the cantata Ino. The works of Georg Friedrich Händel (1685-1759) include the operas Giulio Cesare, Xerxes, and Deidamia along with the pastorals Apollo e Dafne and Acis e Galatea, as well as the oratorios Semele and Hercules. Some of the cantatas of Johann Sebastian Bach (1685-1750) also feature antique myths (Der zufriedengestellte Äolus [The satisfied Aeolus], Streit zwischen Phöbus und Pan [Contest between Phoebus and Pan], and Wabl des Herkules [Hercules' choice]).

Greek myth and Roman history offered the most popular motifs for painters and sculptors, and again Ovid's Metamorphoses was a particular favorite. A number of aristocratic courts started archaeological excavations and collections, and such collections of antiques became a usual feature of a ruler's displays at his court. Pediments, columns, and friezes were retained, and architects followed the prescriptions of Vitruvius, although they did move further away from classical models in other respects. Garden design and architecture was informed by classical myth, particularly 
when the subject matter suited the cult of the ruler (Hercules), and important Baroque gardens were created in Vienna, Dresden, Kassel, and Stuttgart.

Brandenburg/Prussia had an especially strong relationship to classical antiquity. Friedrich Wilhelm (the "Great Elector," 1640-88) was influenced by (neo-)Stoic thought and had already given Roman culture a key role at his court. Statues imitating antique sculpture and pseudoclassical paintings adorned the palace at Berlin, and classically inspired figures were set in the "Lustgarten" (Pleasure garden). Friedrich III (1688-1713, as Friedrich I King in Prussia from 1701) continued this policy with increased vigor. Among the sculptures commissioned by him, the most noteworthy is a statue of himself wearing the dress of a Roman emperor with reminiscences of portrayals of Apollo and Alexander, together with an equestrian sculpture of his father based on that of Marcus Aurelius. He renovated and extended the palace in Berlin, added to the collection of antiques, encouraged the creation of the Thesaurus Brandenburgicus, the greatest catalogue of antiquities of its time, and founded the academies of the arts and sciences.

\section{From Classicism to Romanticism}

Classical antiquity was most influential during the Age of Reason, the "Weimarer Klassik" (Weimar classicism) and the romantic period (from the mid-eighteenth to the early nineteenth centuries). This period was characterized by the gradual development of a bourgeois society, by the growing perception of the Querelle des anciens et des modernes (quarrel of ancients and moderns), and by the resulting tensions between accepting the classical heritage as normative on the one hand and as historical on the other. Traditional rules were discarded while the source material received renewed attention, and classical life - rather than art - was seen as exemplary. This entailed looking less toward classical Rome and more toward Greece, thus emphasizing issues relating to the human condition in general rather than political concerns.

During this period, the reception of antiquity in Germany was closely linked to the rise of classical studies and to the development of a neohumanist notion of education and educational reform. Following the great achievements of Renaissance humanism, at the beginning of the eighteenth century classical philology had focused mostly on compilations, polyhistory, and collections of trifles. However, the increasingly philological and historical approach to antiquity prompted first a reform of how the classics were taught at school and university by philologists such as Johann Matthias Gesner (1691-1761) and Johann August Ernesti (1707-81). Christian Gottlob Heyne (1729-1812) and Friedrich August Wolf (1759-1824) then became the founders of an approach that looked for an encompassing exploration of antiquity that meant to form both the mind and taste. This so-called neohumanism called for a return to the classical sources of European literature, as had the humanism of the Renaissance. It, too, centered on the notion of humanizing society through education and mastery of the languages, but in contrast to earlier humanism, it looked back primarily to Greek, not Roman, art, literature, philosophy, and ways of thinking. One of the most important neohumanists was Wilhelm von Humboldt (1767-1835), a linguist, art 
historian, educator, and liberal politician whose reform of humanist secondary education and founding of the University of Berlin left their mark on the German systems of secondary and higher education. Friedrich Immanuel Niethammer (1766-1848) and Friedrich Thiersch (1784-1860) helped realize the same ideas in Bavaria. During the 1820s the influence of neohumanism saw large sections of German society sympathize with the Greek struggle for independence from the Turks (philhellenism).

Until the middle of the eighteenth century the interests of the courts still held sway over people's thought and actions, which were guided by the key principles of French classicism and clearly belonged to the Rococo period. The architect Georg Wenzeslaus von Knobelsdorff (1699-1753) knew how to combine elegance and austerity, Rococo and classicism in his buildings such as the Berlin opera, the city palace of Potsdam, and the palace of Sanssouci during the reign of Friedrich II (1740-86). Antiquity was ever present in the gardens of Sanssouci, serving to heighten the perceived status of the monarch's rule. Johann Christoph Gottsched (1700-66) attempted to reform German literature, especially drama, with his Versuch einer critischen Dichtkunst (Attempt at a critical art of poetry) and his Deutsche Schanbübne (German stage), guided by the rules and models of the "ancients." Lyricists like Friedrich von Hagedorn (1708-54) and Johann Wilhelm Ludwig Gleim (1719-1803) followed the examples of Anacreon and Horace.

A new start can be clearly discerned from the mid-eighteenth century onwards. In literature there are the three great writers of the high Age of Reason: Friedrich Gottlieb Klopstock (1724-1803), Gotthold Ephraim Lessing (1729-81), and Christoph Martin Wieland (1733-1813), as well as the thinker Johann Joachim Winckelmann (171768). Klopstock's epic Der Messias (The Messiah) introduced the hexameter and Greek mode of expression to German literature, and his odes did the same for other classical meters. Although he increasingly came to prefer Germanic to classical mythology, he remained an admirer of the "ancients" throughout his life. In his works on literary theory (the best known of which are Laocoon and Hamburgische Dramaturgie [Hamburg art of theater]), Lessing took his lead primarily from classical poets and Aristotle's Poetics, thereby clearly shifting the emphasis from Roman to Greek antiquity, without, however, rejecting the Romans in principle. His poetry repeatedly treated subjects from Greek and Roman history (Philotas, Emilia Galotti) or followed classical models (as in his fables and epigrams). Finally, Wieland allowed himself to be heavily influenced by antiquity in his considerable literary oeuvre: in his novels Die Geschichte des Agathon (The story of Agathon), Die Geschichte der Abderiten (The story of the Abderites), Peregrinus Proteus, Agathodümon, and Aristipp und einige seiner Zeitgenossen (Aristipp and some of his contemporaries); in verse epics such as Musarion; in Singspielen (smallscale, often comic operas) like Alceste and Die Wabl des Herkules (The choice of Hercules); in translations (Cicero, Horace, Lucian); and in essays. Unlike many of his contemporaries he avoided any overbearing enthusiasm, any value judgment between Greece and Rome, and any one-sided preference for classical Athens.

Winckelmann clearly provided the main inspiration for the "classical" German view of antiquity (including its illusionist tendencies). The founder of classical archaeology and of art history was the first to set the monuments of classical art in an historical context; he described the essence of this art (in contrast to the Baroque) as "eine edle 
Einfalt und eine stille Größe" (a noble simplicity and a solemn magnificence); he took his lead primarily from Greek art and saw political freedom as lying at the root of its beauty. Certain more normative views, which are evident in his early treatise Gedanken über die Nachabmung der griechischen Werke in der Malerei und Bildhauerkunst (Thoughts on the imitation of Greek works in painting and sculpture), gave way to a historical perspective in his main work Geschichte der Kunst des Altertums (History of classical art).

Johann Gottfried Herder (1744-1803) helped define the reception of antiquity during the Storm and Stress period and Weimar classicism, building on and grappling with Winckelmann and Lessing. His view of antiquity was characterized by a tension between admiring it and viewing it from a historical perspective, by the greater attention he paid to classical life than art, by an emphasis on the differences between Greece and Rome, and by his interest in Greek myth as well as the toning down and humanization of classical paradigms. The most important figure in German literature around 1800 in general, as well as for its relations to antiquity, was Johann Wolfgang

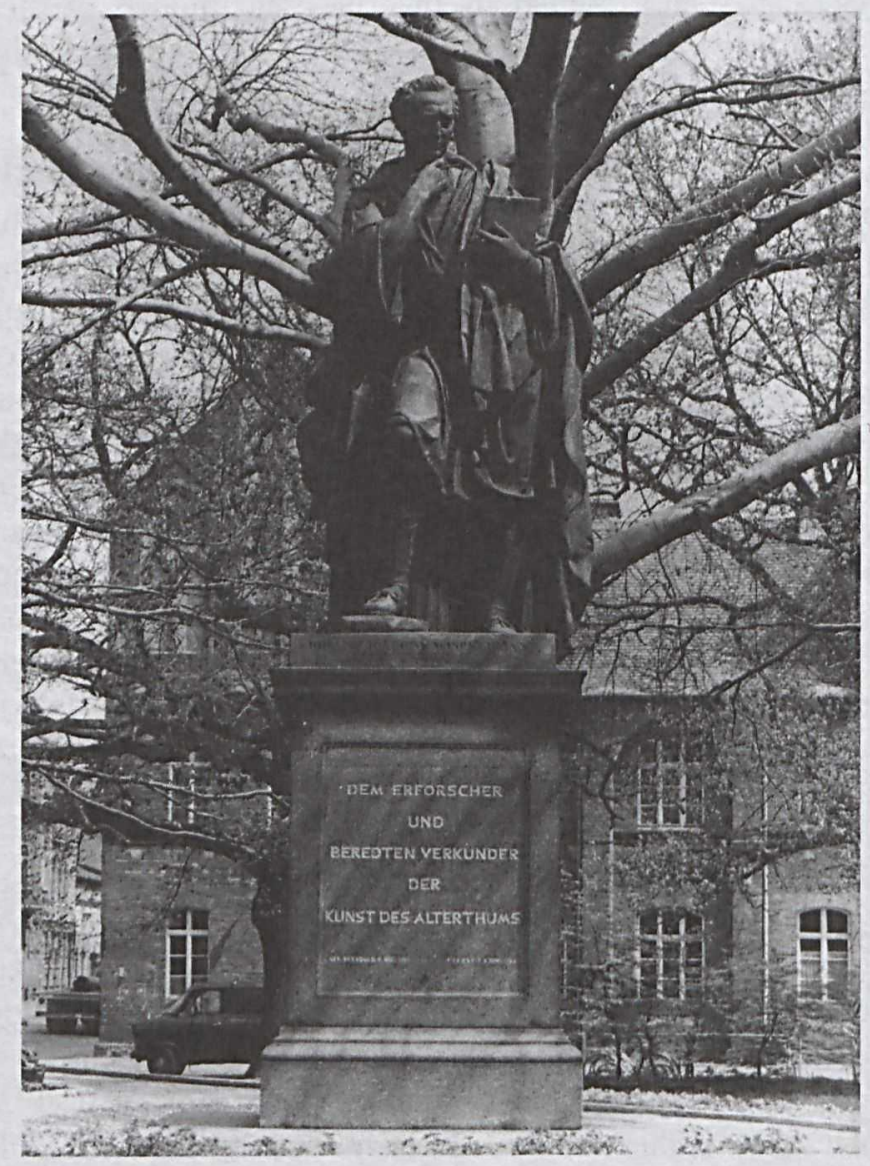

Figure 12.1 Johann Joachim Winckelmann monument in Stendal. Photo: The Winckelmann Museum, Stendal 
Goethe (1749-1832). Already as a young poet in the first half of the 1770s, he felt a strong connection to the Greeks, whom he saw as exemplary for a natural way of life, for a forceful voicing of one's own claim to live, and for an attitude of rebellion (Prometheus, Die Leiden des jungen Werthers [The sorrows of young Werther]). During his first decade in Weimar he proclaimed a harmonic and humane view of the Greeks (Iphigenie auf Tauris [Iphigenia in Tauris]). The "rebirth" he experienced in Italy (1786-8) was primarily a "rebirth" under the overwhelming influence of antiquity, which he felt in its landscape and artifacts. The years between his return from Italy and 1805 saw his most intense engagement with antiquity. He was receptive to love elegy, the art of the epigram, and the didactic poetry of the Romans, but his predominant interest was in the Greeks (epic poetry, lyric, drama). His book Winckelmann und sein Jabrhundert (Winckelmann and his century) marked the culmination and conclusion of Goethe's theoretical efforts (which did not always avoid a normative classicism). The final quarter century of his life shows a continuing appreciation of the "ancients" as well as an extension of his interests and thinking beyond antiquity, as shown, for example, in Faust II.

The friends of the young Goethe during the Storm and Stress period (Jakob Michael Reinhold Lenz [1751-92], Friedrich Maximilian Klinger [1752-1831], Friedrich Müller [1749-1825]) were familiar with antiquity, as were Johann Jakob Wilhelm Heinse (1746-1803), the poets of the Hainbund of Göttingen (among whom Johann Heinrich Voß [1751-1826] stands out for his translation of Homer), and Friedrich Schiller (1759-1805). Roman political motifs predominate in Schiller's early work; in later works, such as the poems Die Götter Griechenlandes (The gods of Greece), Das Ideal und das Leben (The ideal and life), or Das Glück (Fortune) and theoretical writings like Über Anmut und Würde (On grace and dignity) and Über die ästhetische Erziehung des Menschen in einer Reibe von Briefen (On the aesthetic education of man in a series of letters), it is especially Greece that for him embodies a world of harmony, beauty, and unity of opposites. He was, however, well aware of the differences between ancient and modern times and of the fact that Greek art is unique and not to be repeated (Über naive und sentimentalische Dichtung [On naive and sentimental poetry]), and his late poems often exhibit elegiac traits.

Winckelmann also showed the way for the development of visual art and architecture toward harmony and symmetry, clear organization, and delimitation. Among his friends were the painter Anton Raphael Mengs (1728-79) and the architect Friedrich Wilhelm Freiherr von Erdmannsdorff (1736-1800), who created the first purely classicist building in Germany in the palace of Wörlitz near Dessau. Other important exponents of classicism, which remained the dominant style in sculpture and architecture until the middle of the nineteenth century, were the painter and etcher Johann Heinrich Wilhelm Tischbein (1751-1829), and the sculptors Johann Heinrich von Dannecker (1758-1841), Gottfried Schadow (1764-1850), and Christian Daniel Rauch (1777-1857). Significant architects were Carl Gotthard Langhans (17321808), who designed the Brandenburg Gate in Berlin under inspiration from the Propylaea of the Acropolis; Karl Friedrich Schinkel (1781-1841), who left his mark on the townscape of Berlin and Potsdam (Schauspielhaus, Altes Museum, Alte Wache and Nikolaikirche) by using classical elements freely and creatively; and Leo von Klenze 
(1784-1864), whose buildings define the city of Munich by echoing the architecture of Greek temples. The gardens of Wörlitz and Weimar were shaped largely by references to antiquity, and universities first began to collect casts of ancient sculptures.

Enthusiasm for antiquity, mythical subject matters, and classicist inclinations likewise were the hallmarks of the operas of Christoph Willibald Gluck (1714-87). They were meant to match Greek tragedy in their truth, simplicity, and greatness, and their protagonists were characterized by humanity and dignity (Orfeo ed Euridice, Alceste, Paride ed Elena, Iphigénie en Aulide, Iphigénie en Tauride, Écho et Narcisse). Other composers like Joseph Haydn (1732-1809) with his opera L'Anima del Filosofo (Orfeo ed Euridice), Wolfgang Amadeus Mozart (1756-91) with Idomeneo and La Clemenza di Tito, Ludwig van Beethoven with the ballet Gli uomini di Prometheus (The men of Prometheus), and Franz Schubert (1797-1828) with his song Lied des Orpheus, als er in die Hölle ging (Song of Orpheus as he descended to hell) took their plots from classical mythology and history.

During the eighteenth century, classical thinking and schools lost their fundamental importance to philosophy, while it remained characteristic to refer back especially to Plato but also to Heraclitus, the Neoplatonists, and classical natural law. This is true of Immanuel Kant (1724-1804), Johann Gottlieb Fichte (1762-1814), Friedrich Schleiermacher (1768-1834), Friedrich Wilhelm Schelling (1775-1854), Georg Wilhelm Friedrich Hegel (1770-1831), and Arthur Schopenhauer (1788-1860).

In contrast to the writers of Weimar classicism, those of the next generation (Friedrich Hölderlin [1770-1843] and the young Friedrich Schlegel [1772-1829]) often felt an even stronger and more impassioned affinity to Greece, under the influence of the French Revolution and its consequences. They did, however, also introduce some more or less obvious changes. While Hölderlin did not yet question the exemplary nature of Greek art or life in any way, his view of antiquity is determined less by "Apollonian" harmony than "Dionysian" dynamism. In his novel Hyperion and in many of his poems, he reflects the fall of the ancient world in his tragic-elegiac attitude. Classical antiquity was also part of the past for Jean Paul (Johann Paul Friedrich Richter, 1763-1825) and for August Wilhelm Schlegel (1767-1845), in the novel Titan and the elegy Rome, respectively. Heinrich von Kleist's (1777-1811) Amphitryon introduces tragic conflict into a subject matter traditionally employed for comedies, and shows a world characterized by deceit, confused emotions, and loss of identity. In his Penthesilea he focused for the first time on the "dark side" of an archaic-barbaric antiquity and explicitly freed himself from a "classical" view of the Greeks. Friedrich Schlegel was the leading theorist of the early Romantics. He developed from a critic to a defender of modernism and called for the creation of a "new mythology." The philosopher Schelling and the classicist Georg Friedrich Creuzer (1771-1858) also contributed greatly to this novel renaissance of myth. In general, romantic writers, especially after 1800 , turned away from using classical themes to Christian, medieval, oriental, and modern (national) subject matters. We can even see classical antiquity become less valued in favor of Christianity (for instance in the novella Das Marmorbild [The marble image] by Joseph Freiherr von Eichendorff [1788-1857]). As heir of the "Kunstperiode," the Austrian writer Franz Grillparzer (1791-1872) was the only one to attempt to portray common human experiences through classical materials (Sappho, 
Das goldene Vließ [The golden fleece], Des Meeres und der Liebe Wellen [The ocean's and love's waves]). Romantic painting likewise did not view the art of the "ancients" as providing guiding rules and principles, least of all aesthetic norms.

\section{The Nineteenth Century}

The nineteenth century (including the first decades of the twentieth century) represents the "great time" of German classical studies, which had been developed on strict historical foundations with meticulous research into philological, historical, and archaeological details since August Boeckh (1785-1867). Well-known scholars of this time included the ancient historian Theodor Mommsen (1817-1903), the philologists Friedrich Ritschl (1806-76), Friedrich Leo (1851-1914), and Ulrich von Wilamowitz-Moellendorff (1848-1931), the historians of philosophy Eduard Zeller (1814-96) and Hermann Diels (1848-1922), and the archaeologists Ernst Curtius (1814-96), Heinrich Schliemann (1822-90), Wilhelm Dörpfeld (18531940), and Adolf Furtwängler (1853-1907). It was during this period that academic projects on a grand scale, such as the "Bibliotheca Teubneriana" series of classical texts, the compendia Realencyclopädie der classischen Altertumswissenschaft (Factual encyclopedia of the study of classical antiquity) and Handbuch der classischen Altertumswissenschaft (Manual of the study of classical antiquity), the dictionary Thesaurus linguae Latinae (Treasure of the Latin language), and the collections of inscriptions Inscriptiones Graecae (Greek inscriptions) and Corpus inscriptionum Latinarum (Collection of Latin inscriptions), were initiated. Excavations commenced in Troy, Olympia, Aegina, and Pergamon. Scientific academies, universities with their departments of classical studies, museums (especially in Berlin and Munich), and collections of antiquities and casts became important centers of academic life.

In contrast to fundamental research with a positivistic bend, the Swiss scholars Johann Jacob Bachofen (1815-87) and Jacob Burckhardt (1818-97) aimed at a new appreciation of classical culture as a whole, which included turning away from an idealizing view of the Greeks. New theoretical approaches were also developed in philosophy: in the sociocritical reading of antiquity by Karl Marx (1818-83) and Friedrich Engels (1820-95) as well as in Friedrich Nietzsche's (1844-1900) ecstatic "Dionysian" view of antiquity, which was markedly different from the harmonic "Apollonian" understanding of the classical period.

These scholars threw light on the "dark side" of antiquity. The detailed research in the field of classical studies also mostly avoided the preceding period's tendency to emphasize the heroic. Yet traditional views still prevailed in popular writings and in the educational system, which mostly continued Humboldt's approach, though with somewhat less breadth. Although the position of the "Humaniora" remained secure, changes in literature that had been developing since 1800 gained currency, and a "realistic" rendering of a bourgeois environment became dominant. The reception of classical antiquity lost much of its importance during the course of the nineteenth century - not so much quantitatively as in its perceived role as offering a dominant worldview and/or as in its artistic standards. On the one hand, we see a flattening, 
trivialization, and derivative imitation of the classics - Gustav Schwab (1792-1850), for instance, explicitly recounted the "schönsten Sagen des klassischen Altertums" ("most beautiful myths of classical antiquity"); on the other, the tendency to use antiquity for nationalistic purposes grew steadily (clearly from 1866, the year of Prussia's victory over Austria), as in the novel Ein Kampf um Rom (A battle for Rome) by Felix Dahn (1834-1912).

Significant works with classical motifs were, however, still being produced. Heinrich Heine (1797-1856) definitely recognized antiquity as part of the past and often satirized it, but he also saw it, in the end, as the goal of his elegiac longing. Christian Dietrich Grabbe (1801-36) portrayed historical processes in a number of plays on Roman subject matters without any illusions. Democratic convictions and a sharp anticlerical stance were met by a strong inclination toward the formal and classical in August Graf von Platen-Hallermünde (1796-1835). Because he felt that his inner nature resonated in sympathy with that of Anacreon, Theocritus, Catullus, Horace, and Tibullus, Eduard Mörike (1804-75) liked to render personal subjects in quasiclassical tones. Friedrich Hebbel (1813-63) wrote Gyges und sein Ring (Gyges and his ring), using Herodotus and Plato, a tragedy exploring issues of power, tradition, and achievement. In his Ring des Nibelungen, Richard Wagner (1813-83) consciously combined a story from Germanic myth with the world of the gods of the Iliad and the structure of Aeschylus' Prometheus plays.

The work of Wagner is significant for the history of literature, as well as of music and of the theater. While German music of the mid-nineteenth century for the most part was not concerned with antiquity, the first production of an original classical play (in translation) took place in 1841 with Sophocles' Antigone, directed in Potsdam by Ludwig Tieck (1773-1853). This new trend toward a classical revival in the theater was continued by other productions directed by Tieck in Potsdam as well as by performances in Munich, Meiningen, and Vienna.

Classical subject matters also played a role in painting without being dominant. Anselm Feuerbach (1829-80) strove to renew Greek beauty by means of a grand style and decorative composition (Medea, Amazonenschlacht [Battle of the Amazons], Iphigenie, Gastmabl des Platon [Plato's feast]). The Swiss painter Arnold Böcklin (1827-1901) tried to revive fundamental moods and concepts of antiquity (Triton und Nereide, Im Spiel der Wellen [In the play of the waves]). The genre of historical painting was cultivated by Karl Theodor von Piloty (1826-86) (Die Ermordung Cüsars [Caesar's murder], Tod Alexander des Großen [Death of Alexander the Great]). Hans Makart (1840-84) created a Triumph der Ariadne (Triumph of Ariadne) and a Tod der Kleopatra (Death of Cleopatra). Max Klingner (1857-1920) employed classical ideas and forms in a unique, creative manner (Amor und Psyche, Urteil des Paris [Paris' judgment], Kassandra).

\section{The Twentieth Century}

During the twentieth century, classical studies and education were characterized by a marked decline in the teaching of the ancient languages, in particular Greek, and by 
the conservative stance of many practitioners, which led to close relations to those in power, both under the rule of the Kaiser and under the National Socialists. As a consequence, those secondary schools that taught classics were often criticized for being remote from the real world and for having a submissive attitude. This attitude is also evident in the last attempt so far to derive guiding principles for society from antiquity: the "Third Humanism" founded by Werner Jaeger (1888-1961). Mainly a reaction to Germany's defeat in World War I, to the November Revolution and democracy, it bore quasi-religious traits and was directed - in contrast to neohumanism - toward the state, not the individual.

The ideology of National Socialism represented a low point despite the fact that overall it saw itself less indebted to antiquity than did Italian fascism. Nevertheless its leading exponents - foremost among them Hitler himself - appealed to Sparta and Rome, interpreted classical history according to their theory of race, and aimed for heroic-monumental state architecture. After 1945 classical traditions were seen in close relationship to Christianity ("Abendlandideologie" [Ideology of the occident]) as part of how West Germany understood itself politically, while they did not assume any direct ideological role in the German Democratic Republic.

Still Greek and Roman times remained important in the twentieth century. Significant research continued to take place in philology, archaeology, and ancient history. Numerous translations and editions of texts prove that antiquity remained of interest to many readers. Philosophers of many different schools (from Edmund Husserl [1859-1938] and Martin Heidegger [1889-1976] to Ernst Bloch [1885-1977], Max Horckheimer [1895-1973], and Theodor W. Adorno [1903-69]) engaged with questions raised by Greek philosophy, mythology, and literature. When founding psychoanalysis, Sigmund Freud (1856-1939) reached back to the ancient myths ("Oedipus complex"), and the arts, first and foremost, were characterized much more by classical motifs than in the nineteenth century. The dominant mode was a critical and questioning approach to the models, following Marx, Nietzsche, and Freud: influenced by their own experiences of extreme crises, many writers, painters, sculptors, and composers viewed antiquity as a time of incredible social and political tensions. They stressed the barshness of ancient myths, questioned conflicts from a psychological perspective, and understood antiquity less in an "Apollonian" than in a "Dionysian" fashion. It was no longer a single author, work, genre, or period that was crucial for the reception of antiquity, but the received subject matters were seen as a freely available reservoir of motifs, a trend that had begun since the Romantic period. Linked to the general tendency for art to become more political, Rome again assumed a larger role despite the primacy of Greece.

The newly awakened interest in antiquity started with the postnaturalistic literature of the turn of the century. In drama Gerhart Hauptmann (1862-1946), Frank Wedekind (1864-1918), and Hugo von Hofmannsthal (1874-1929) played a part; in lyric, besides Hofmannsthal, Stefan George (1868-1933) and Rainer Maria Rilke (1875-1926); and in prose writing, Heinrich and Thomas Mann (1871-1950 and 1875-1955, respectively). In his travelog Griechischer Frübling (Greek spring) and his drama Der Bogen des Odysseus (The bow of Odysseus), Hauptmann turned his attention toward the darker aspects of antiquity. His late Atrides tetralogy still reflected, in 
its ever-present engagement with Aeschylus, Sophocles, Euripides, and Goethe, the experiences of World War II. Wedekind portrayed human sexuality as an elemental force destroying societal norms in Erdgeist (Earth spirit) and Die Büchse der Pandora (Pandora's box); in Heracles he showed a suffering and disappointed hero. Hofmannsthal's Electra virtually offers an exemplary psychological interpretation of myth reaching back to, and turning away from, Sophocles, Goethe, and Shakespeare. With Ödipus und die Sphinx (Oedipus and the Sphinx), Ariadne auf Naxos (Ariadne on Naxos), and Die ägyptische Helena (The Egyptian Helena), he likewise turned toward a subtle and sensitive exploration of the dark recesses and undercurrents of the soul. While George employed a fair amount of pathos and force in his attempts to see classical norms valued, Rilke reenacted human liminal experiences in a very moving way in poems such as Alcestis or Orpheus. Eurydice. Hermes. He also sought to suspend the tragic nature of life, love, and art in the "Raum der Rühmung" (Room of glorifying) in the Sonetten an Orpheus (Sonnets to Orpheus). In his novel Die Göttinnen (The goddesses), Heinrich Mann celebrated "die große heidnische Sinnlichkeit" (the great pagan sensuality) by means of the mythological roles of Diana, Minerva, and Venus. His novella Die Rückkehr vom Hades (The return from Hades) reflected the precarious relationship of the artist and his public. Thomas Mann's novella Der Tod in Venedig (Death in Venice) narrates a modern journey to Hades. In it, hints of Plato's thoughts on love and beauty move from an atmosphere of a classicism echoing antiquity to Dionysian intoxication, ending in chaos and barbarism. Reminiscences of antiquity also pervade his novels Der Zauberberg (The magic mountain), Joseph und seine Brüder (Joseph and his brothers), and Doktor Faustus.

Expressionism referred back to antiquity more strongly than some theoretical pronouncements would lead one to expect: thus in the poems of Georg Heym (1887-1912) and Ywan Goll (1891-1950), in the antimilitaristic plays Die Troerinnen (The Trojan women) by Franz Werfel (1890-1945) and Antigone by Walter Hasenclever (1890-1940), in Hans Henny Jahnn's (1894-1959) Medea, which combined both antiracism and social criticism with basic instincts and archaic behaviors, and in a number of pieces by Georg Kaiser (1878-1945). References to antiquity pervade the prose writings of Franz Kafka (1883-1924), partly under the surface, such as the labyrinth- and Oedipus-motifs, partly in new deconstructive interpretations that alter and remove the heroic (in Das Schweigen der Sirenen [The silence of the sirens], Prometheus, Poseidon). This is also true in the works of Albert Ehrenstein (1886-1950) and Gottfried Benn (1886-1956). Benn began as a "dionysischer Rauschkünstler" (Dionysian intoxication-artist) under the influence of Nietzsche, but later identified himself more with the artist Orpheus, advocated an Apollonian-intellectualizing view of antiquity, and emphasized the tragic content of the ancient myths. Immediately following the establishment of the Nazi dictatorship, he proclaimed his allegiance to a total state founded on violence, terror, and leadership in his essay Dorische Welt (The Doric world), using Sparta as an example.

Antifascist authors who were active primarily during the Weimar Republic and the years of exile became radicalized in their social and political pronouncements, focusing particularly on Roman antiquity - for instance in Ödön von Horvárth's (1901-38) comedy Pompeji, in Lion Feuchtwanger's (1884-1957) novels Der 
jüdische Krieg (The Jewish war) and Der falsche Nero (The false Nero), or in Hermann Broch's (1886-1951) novel Der Tod des Vergil (The death of Virgil). Broch used the figure of the Roman poet and his relations with Augustus to deal with issues such as the meaning and value of art and its relationship to politics, from the experiences of fascism and exile. He debated fundamental questions concerning the antagonism of truth and beauty or of glory and insignificance, and he reflected on the responsibility of the creative individual who can be both revered as a bringer of salvation and manipulated by power.

Among the "left"-leaning writers of the first half of the twentieth century, Bertolt Brecht (1898-1956) was the one who showed the most engagement with classical motifs. He reinterpreted traditional history and mythology in a distancing and nonheroic manner (Berichtigungen alter Mythen [Corrections of old myths], Die Geschäfte des Herrn Julius Cösar [The affairs of Mr. Julius Caesar], Das Verhör des Lukullus [The trial of Lucullus]). Yet he also showed the exemplary nature of classical events for social behavior today (Die Horatier und die Kuriatier [The Horatii and the Curiatii], Briefe über Gelesenes [Letters on what has been read], Coriolanus [after Shakespeare]), and proved his sympathy for personalities of the ancient world in a simple and unaffected way (Der Schuh des Empedokles [The shoe of Empedocles], Der verwundete Sokrates [The wounded Socrates]). With Die Antigone des Sophokles. Nach der Hölderlinschen Übersetzung (The Antigone of Sophocles. After the Translation by Hölderlin), Brecht

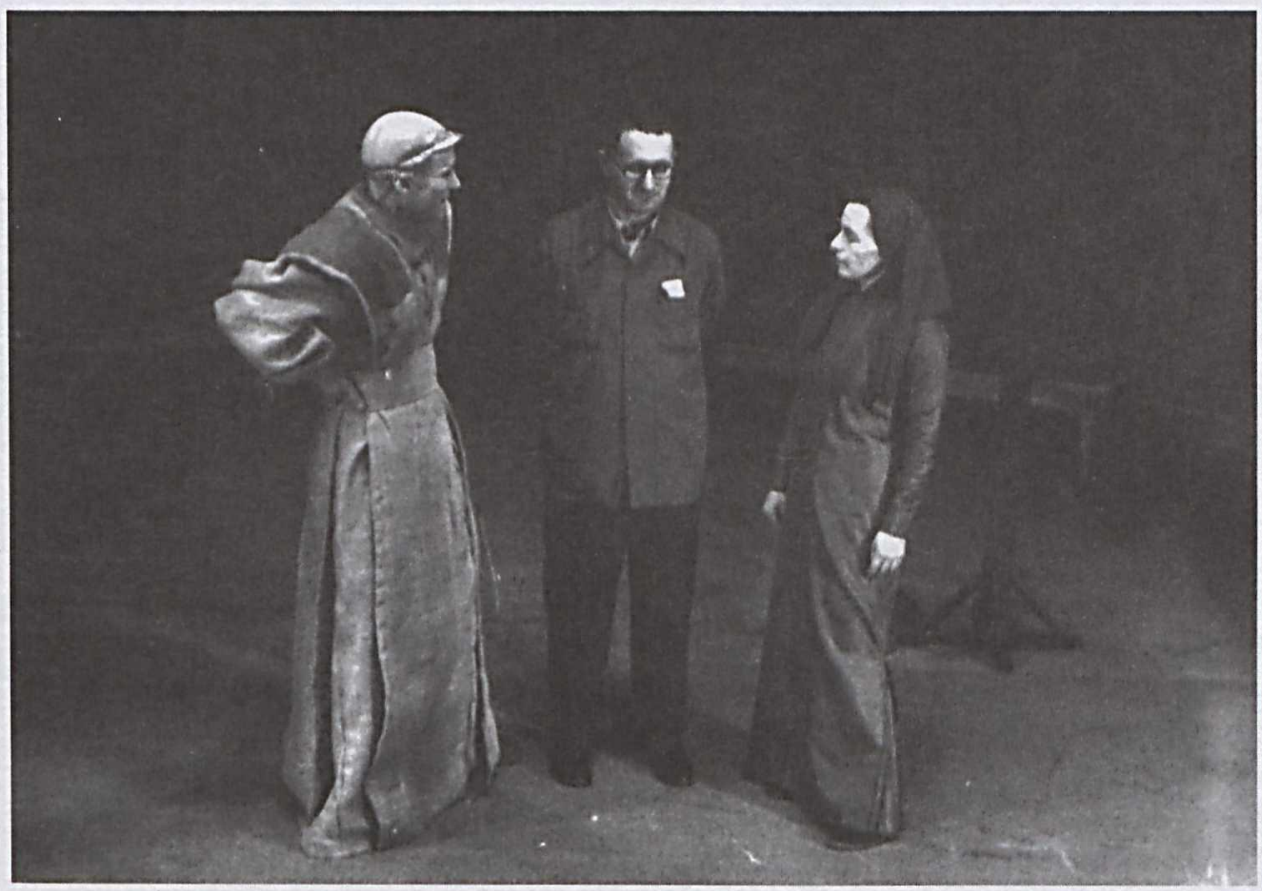

Figure 12.2 Bertolt Brecht at the dress rehearsal of his play The Antigone of Sophocles in Chur (Switzerland, February 15, 1948), with Helene Weigel as Antigone and Hans Gaugler as Creon. Photo by Ruth Berlau, reproduced with permission of Hilda Hoffman. Bertolt-BrechtArchiv, Berlin 
gave the impetus for the reception of antiquity in the following decades in a number of ways: in the visible role of the dramatic, in the close affinity to the genre of adaptations, in the sociocritical emphasis, the politicization, and "Durchrationalisierung" (thorough rationalization) of the material, in the nuanced relationship between continuation and contrast, and not least also in the appreciation of Hölderlin.

The reception of classical motifs in the literature of the late forties and early fifties is marked for the most part by the historical experiences of the war and postwar period: by terror and death, exile and return, conformity and opposition, a fresh start and disillusionment. At first elements of identification and affirmation predominate, as an echo of traditional "humanist" attitudes as well as an attempt to "appropriate" the classical "inheritance" for socialist purposes. Later, however, the critical-questioning approach clearly prevails. The increased literary interest in classical subject matters in general, and the critical interpretation of the traditional myths in particular, owe much to the reception of antiquity in French theater since the end of the twenties (André Gide, Jean Giraudoux, Jean Cocteau, Jean Anouilh, Jean-Paul Sartre, Albert Camus) and in the works of the American dramatist Eugene O'Neill and the writers of lyric and essays, the Englishman T. S. Eliot and the American Ezra Pound.

The work of the Swiss authors Max Frisch (1911-91) and Friedrich Dürrenmatt (1921-90) is rooted in the postwar period. They employed the Odysseus- and Oedipus-motifs in the novels Stiller and Homo faber (Man the maker) and expressed a non-heroic view of history in the plays Romulus der Große (Romulus the great) and Der Stall des Augias (The stable of Augias). Heinrich Böll (1917-85) calls the militaristic interpretation of antiquity in German schools to account in his story Wanderer, kommst du nach Spa ... (Wanderer, when you come to Spa ...); Arno Schmidt (1914-79) has taken a critical attitude to classical myths and events, and transformed them into travesty, in a range of stories in the volumes Leviathan oder Die beste der Welten (Leviathan or the best of worlds) and Kübe in Halbtrauer (Cows in half mourning). While the reception of antiquity was generally in decline in West German literature after the fifties, it remained a constant presence in the work of the classical philologist Walter Jens (born 1923) from Tübingen. In the literature of the German Democratic Republic, classical influences became evident, first in the fifties, especially in lyric poetry. The use of traditional motifs in a positive, affirmative manner, which Johannes R. Becher (1891-1958) had been developing since the thirties and which he now continued in a fairly linear fashion, proved in the end to be less effective. In contrast, the early poems of Stephan Hermlin (1915-97) have elegiac and questioning traits, and the late lyrics and essays by Erich Arendt (1903-84) show a characteristic development from positive identification to distancing, a distancing that applies both to the classical heroes and to the socialist present (Odysseus' Heimkehr [Odysseus' return] and other poems from the cycle Ägüis [Aegean]). The rejection of history goes hand in hand with an endorsement of nature and art (Gesang der sieben Inseln [Song of the seven islands], Stunde Homer [Hour Homer]). Pensive reflections are also characteristic of Georg Maurer's (1907-71) and Johannes Bobrowski's (1917-65) lyric poetry, and Peter Huchel's (1903-81) poems are characterized particularly by elegiac moments of resignation (Polybius, Der Garten des Theophrast [The garden of Theophrastus], Das Grab des Odysseus [The grave of Odysseus]). 
It is notable that engagement with antiquity during the second half of the twentieth century became a key characteristic of writers in the German Democratic Republic. It allowed them to create a poetry addressing fundamental concerns, to escape a narrow definition of realism, and to debate the issues of their own time without prejudice. Since about 1960 this literature has been influenced not only by fascism and war but also by the circumstances of the postwar period. Drama was the dominant genre at the beginning of this phase: the production of Peter Hacks's (1928-2003) reworking of Aristophanes' Frieden (Peace) in 1962 in Berlin was one of the most successful plays in German-speaking countries after 1945. With plays such as Amphitryon, Omphale, and Numa or later with the Die Vögel (Birds) (after Aristophanes), Senecas Tod (Death of Seneca), and Pandora (after Goethe), Hacks explored the tensions in the relationship between utopia and reality with the help of classical subject matters. For the most part he adopted a positive stance toward both literary tradition and socialist society. The works of Heiner Müller (1929-95), on the other hand, offer an example of a more critical approach to traditional subjects. In plays like Philoktet, Heracles 5, Ödipus Tyrann (Oedipus tyrant) (after Sophocles), Der Horatier (The Horatian), and Zement (Cement) (after a novel by Fjodor Gladkow), Müller employed the ancient myths to portray the problems of the (mostly socialist) present - especially the conflicting interests of individuals and of society - in sharp focus. In lyric poetry, a differentiated engagement with traditional subject matters continued with authors such as Günter Kunert (born 1929), Karl Mickel (1935-2000), Heinz Czechowski (born 1935), and Volker Braun (born 1939) (who were also active in other genres). Over the last decades, these authors have been joined by Durs Grünbein (born 1962), whose interest lies mainly in Roman history, with his historical-philosophical perspective and sobering diction. Among writers of prose narrative, Franz Fühmann (1922-84) and Christa Wolf (born 1929) should be mentioned. Fühmann echoed the guilt and delusion of German soldiers in World War II in his story König Ödipus (King Oedipus) and created an intelligent adaptation of Homeric epic (Das Hölzerne Pferd [The wooden horse]). In his "mythological novel" Prometheus, and in a number of stories, he questioned the conflict between "Geist und Macht" (spirit/mind/intellect and power). In Kassandra, Christa Wolf challenged war and the politics of power, violence, and ideological manipulation - a challenge that means grappling with a patriarchal world and with the dangers of a one-sided rationalism, and that does not flinch in questioning the price to be paid for the progress of society and technology, and that repudiates all "heroism." However, human interactions and the use of political power are discussed in even more fundamental and subtle ways in Medea. Stimmen (Medea. Voices). This work also reflects experiences since the collapse of the "socialist camp" in Europe and its return to the "Western World," and enacts a radical turn away from the Euripidean version of Medea as child-murderer.

Since the seventies interest in classical subjects has also been renewed in the German literature of the Federal Republic of Germany, Austria, and Switzerland and in countries inhabited by German exiles. This work similarly tends to take a critical approach, as do Peter Weiss (1916-82) and Botho Strauß (born 1944) as well as the Austrian writers Christoph Ransmayr (born 1954) and Michael Köhlmeier (born 1949). Weiss's novel 
Die Ästhetik des Widerstands (The aesthetic of resistance) sets the antifascist resistance in the context of a process of two thousand years of social conflict. It poses the question of a radical "appropriation" of the artistic "inheritance" in order to resolve one's own existential questions - the great frieze of the Pergamon altar and the interpretation of Heracles with all his duality play a significant role in this. Strauß lets the mythological appear among the everyday in a number of his pieces and offers an emphatically conservative reading of Homer in Ithaca. In Ransmayr's novel Die letzte Welt (The last world), Ovid's Metamorphoses virtually piece themselves together out of the life of the poet, who, victimized by a tyrant, has been exiled to Tomi, and out of the investigations of the narrator. Köhlmeier mixes divine and human action from stories related to the Homeric epics with a modern ambience in his Odysseus novels Telemach and Kalypso and leaves much room for irony and persiflage.

The reception of antiquity in other forms of art is more or less closely related to literature. In theater, there were the epoch-making productions of the Oresteia by Max Reinhardt (1873-1945) and of Oidipus by Leopold Jessner (1878-1945) during the Weimar Republic. In the eighties, Peter Stein's (born 1937) staging of the Oresteia at the Berlin Schaubühne, the Schwerin project "Entdeckungen 'Antike' " (Discoveries "antiquity") by Christoph Schroth (born 1937), and the five Theater Festivals of Stendal stand out. The rendition of authentic classical plays (in translation), the staging of adaptations, and the production of modern plays on classical topics regularly form part of the play-lists and sometimes are in fact linked with each other.

Classical (mostly mythical) subjects have become increasingly popular again in music, especially musical theater. Richard Strauss (1864-1948) is among the first. His operas Elektra, Ariadne auf Naxos (Ariadne on Naxos), and Die ägyptische Helena (The Egyptian Helena) were created to the libretti of Hugo von Hofmannsthal. Later Walter Braunfels (1882-1954) composed Die Vögel (The birds, after Aristophanes), Egon Wellesz (1885-1974) Alkestis and Bacchantinnen (Bacchantes) (after Euripides), Ernst Křenek (1900-91) Orpheus und Eurydike, Das Leben des Orest (The life of Orestes), and Pallas Athene weint (Pallas Athena cries), and Rudolf Wagner-Régeny (1903-69) Prometheus. Heinz Röttger (1909-77) and Aribert Reimann (born 1936) adapted in Die Frauen von Troja (The women of Troy) and Troades works by Euripides and Franz Werfel, respectively. Paul Dessau (1894-1984) created the opera Das Verhör des Lukullus (The trial of Lucullus) after Brecht. Carl Orff (1895-1982) often set original Greek and Latin texts to music (like the Prometheus of Aeschylus, Sophocles' Oedipus, the Catulli Carmina, or the medieval Carmina Burana); he chose Hölderlin's translation for his Antigone, after Sophocles. Rolf Liebermann (1910-99) wrote the operas Penelope and Freispruch für Medea (Acquittal of Medea), Hans Werner Henze (born 1926) the ballet Orpheus. From the last decades we have the opera Ödipus (after Sophocles and Heiner Müller), the cello concerto Styx und Lethe (Styx and Lethe) by Wolfgang Rihm (born 1952), and Kassandra. Starrend von Zeit und Helle (Cassandra. Rigid with time and brightness) and a Musiktheater in sechs Gedichten von Erich Arendt (Musical theater in six poems by Erich Arendt) by Peter Michael Hamel (born 1947). Then there are the operas Die Heimkehr des Odysseus (The return of Odysseus) and Omphale (after Hacks), a dramatic score to the Oedipus-tragedies of Sophocles, 
and musical renditions of Catullus by Siegfried Matthus (born 1934), as well as the operas Gastmabl oder Über die Liebe (Banquet or on love) and Antigone oder Die Stadt (Antigone or the city) by Georg Katzer (born 1935).

The fine arts also utilized classical subjects. From the first half of the twentieth century the sculptor Gerhard Marcks (1889-1981) and the painter Max Beckmann (1884-1950) ought to be mentioned. Marcks engaged with classical myths during his whole life (Orpheus-Mappe [Orpheus-portfolio], Ödipus und Antigone, Gefesselter Prometheus [Prometheus bound]); Beckmann preferred to work on mythical subject matters during his exile in the 1940s (Mars und Venus, Perseus, Prometheus, Odysseus und Kalypso). Gustav Seitz (1906-66), Hans Arp (1888-1966), and Bernhard Heiliger (1915-99), among others, engaged with classical motifs on occasion during the second half of the century. The reception of classical antiquity flourished in the arts of the German Democratic Republic, as it did in its literature. It provides nothing less than the foundation for the work of the sculptor Wieland Förster (born 1930), who reflects painful experiences of the individual and society through the motif of the labyrinth and through figures like Daphne, Nike, and Marsyas, and for the painter Wolfgang Mattheuer (1927-2004), who repeatedly turned to the myths of Sisyphus and Icarus. Bernhard Heisig (born 1925), who also paid special attention to the figure of Icarus, and Werner Tübke (1929-2004) created further works illustrating this trend. Besides Icarus, Prometheus, the judgment of Paris, and Cassandra are favorite themes (on whose reception through the ages there have already been a number of exhibitions).

During the very times of crisis, of historical change and seeming distance from antiquity, subjects from the Greek and Roman past can serve as the focal point for topical debates by stimulating a turning away from conventional interpretations and an emphasis on ruptures and discontinuities. This is proof that the heritage of antiquity retains a life and influence beyond all monumentality and classicality.

\section{FURTHER READING}

On Goethe and the Greeks, see Trevelyan (1941); from the eighteenth to the twentieth centuries, see Butler (1935); on the classical tradition in twentieth-century Germany, see Ziolkowski (1993). Much good material remains accessible only in German: see especially the collections edited by Baumbach (2000), Faber and Kytzler (1992), and Seidensticker and Vöhler (2001), along with the books by Cancik (1998) and Riedel $(1996,2000,2002)$. Much useful information is available in Cancik, Schneider, and Landfester (1996-2003), Der neue Pauly: Enzyklopädie der Antike, whose last five volumes are devoted to the classical tradition, with a pronounced German slant. These volumes are being translated into English and published by E. J. Brill, with the first volume having been published in 2006 .

This chapter has been translated by Kathrin Lüddecke. 